\title{
De "salvajes" a heroicos: la construcción de la voz y la imagen del "indio Charrúa" desde 1830 a los inicios del siglo XX
}

\author{
Andrés Azpiroz \\ FHCE - Udelar - Museo Histórico Nacional \\ Montevideo - Uruguay
}

\section{Resumen}

El artículo se centra en el análisis del recorrido del concepto de"indios charrúas"desdelacreacióndelEstadoOrientalhastalasprimerasdécadas delsigloXX.Desdeuna perspectiva dela historia conceptual seanalizan los diversos significados dela voz"charrúa"a través de fuentes escritase iconográficas. De la lectura del artículo se advierte el proceso complejo por el cual el concepto pasó desde una tradición negativa, asociada al concepto de salvaje, a una valoración positiva relacionada con la incorporación deesegrupodeindígenasalaidentidadnacional delUruguay.

\section{Palabras Clave}

Indios charrúas; Historia Conceptual; Uruguay.

* Magíster en Ciencias Humanas opción Historia Rioplatense por la Facultad de Humanidades y Ciencias de la Educación. Doctorando en Historia por la misma facultad. Docente del Departamento de Historia de la Facultad de Humanidades y Ciencias de la Educación y Director del Museo Histórico Nacional. E-mail: andresazpiroz@gmail.com. 


\title{
From "savages" to heroes: the construction of "indio Charrúa" utterance from 1830 to the early twentieth century
}

\author{
Andrés Azpiroz \\ FHCE - Udelar - Museo Histórico Nacional \\ Montevideo - Uruguay
}

The article analysis of the concept referring to the "indios charrúas" and the course it took progressively from the beginning of the Estado Oriental toward the 1 st decades of the 20th century. From a conceptual history's perspective, diverse meanings of the "charrúa"'s utterance were examined closely through written and iconographic sources. By reading the article, a very complex process is appreciated: how such a negative concept, associated to the word "savage" was transformed into a positive one, due to the integration of that group of "savages" to Uruguays national identity.

Charrúas; Conceptual History; Uruguay. 


\title{
De "selvagens" a heróis: a construção da voz e da imagem do "indio Charrúa" de 1830 até início do século XX
}

\author{
Andrés Azpiroz \\ FHCE - Udelar - Museo Histórico Nacional \\ Montevideo - Uruguay
}

O artigo centra-se na análise do percurso do conceito de "índios Charruas" desde a criação do Estado Oriental até as primeiras décadas do século XX. Do ponto de vista conceitual da história os vários significados da palavra "Charrúa" através de fontes escritas e iconográficas são analisados.Daleitura doartigo, adverteocomplexo processoatravés do qual o conceito passou de uma tradição negativa associada com o conceito de um selvagem, à avaliação positiva relacionada com a inclusão desse grupo indígena a identidade nacional do Uruguai.

\section{Palavras-Chave}

Charrúas; História dos Conceitos; Uruguai. 
En el Uruguay prevaleció hasta hace poco tiempo la imagen de un país sin indios resultado de múltiples olas inmigratorias que habían generado, según el sociólogo Germán Rama, una sociedad "hiperintegrada", donde el Estado promovió la integración a través de la educación laica, gratuita y obligatoria, universalizó el voto y dio un marco de recepción a los inmigrantes ${ }^{1}$. Sin embargo, en las décadas de 1980 y 1990, como consecuencia de la agudacrisiseconómicasurgieronmovimientossocialesquepusieronenduda esos conceptos y reivindicaron el lugar de los indígenas y afrodescendientes en la conformación demográfica del Uruguay ${ }^{2}$. Al respecto Isabel Barreto y Leonel Cabrera han señalado que la construcción de la memoria colectiva se realizó desde una matriz europea y como resultado la visión sobre los indígenases"vagaycontradictoria"ytransitadesde"laexaltacióndelagarracharrúa hastaelpobreconceptode'bárbaro,"salvaje'yprimitivo"3. Estecambiodeimageny autopercepcióndelosgruposindígenasquehabitaronelterritorioqueocupa el Uruguay, se aprecia en los resultados del censo de 2011, cuando al incluir lapregunta“ ¿Creetenerascendenciaindígena?,el5,1\%delapoblaciónsemanifestó afirmativamente ${ }^{4}$.

Teniendo en cuenta este periplo que hemos sintetizado, el siguiente trabajo analiza algunos de los recorridos en la construcción del concepto y las imágenes del "indio charrúa" desde la conformación del Estado Oriental hasta finales del siglo XIX, cuando se configuró una idealización del pasado indígena asociada al proceso de construcción de la "identidad nacional". Desdeformas discursivas diversas, comoeltextohistoriográficodeFrancisco Bauzá, la poesía de Juan Zorrilla de San Martín y la obra plástica de Juan

1 RAMA,Germán.Lademocracia en Uruguay.Unaperspectivadeinterpretación.Montevideo:Editorial Arca, 1989.

2 Sobre las características del discurso de las sociedades neoindigenistas en Uruguay Cf. PORZECANSKI, Teresa. Las raíces indígenas: mito y realidades, en La Gaceta Revista de la Asociación de Profesores de Historia del Uruguay, Montevideo, n²2, abril 2002.

3 CABRERA PÉREZ, Leonel; BARRETO, Isabel. Indios, frontera y hacendados en el sur de la Banda Oriental. En: BEHARES, Luis; CURES, Oribe. Sociedad y cultura en el Montevideo colonial. Montevideo: Facultad de Humanidades y Ciencias de la Educación, 1997, p. 260.

4 CABELLA, Wanda; NATHAN, Mathías. Iguales y diferentes .En: Colección Nuestro Tiempo, Libro de los Bicentenarios, n 20, p. 17 - 18. Disponible en http://www.bibliotecadelbicentenario.gub. uy/innovaportal/file/62986/1/nuestro-tiempo-20.pdf. Acceso 22 de julio de 2016. 
Manuel Blanes, se expresaron las transformaciones en la valoración de este grupo amerindio y su incorporación en un relato fundante de la nación.

El proceso no es lineal pues hasta buena parte del siglo XX prevaleció, incluso en libros de texto, una definición y una imagen de los charrúas inmutable y asociada a su naturaleza de guerreros, "indómitos", "valientes" y"belicosos". Como señala el historiador Javier Fernández Sebastián en relaciónalanaturalezahistóricadelosconceptos:"Habría,pues,unamplioabanico deusosyjuegosdellenguaje,parcialmentesolapadosycoincidentes,escierto,perotambién parcialmente discrepantes y contradictorios" ${ }^{\prime 5}$.

El análisis centra su mirada en el concepto de "indio charrúa"y advierte losdiversossentidosyvaloraciones, avecessimultáneosycontrapuestos, que adquirió la voz en poco más de cincuenta años. Con el objetivo de buscar significados en diversas fuentes, junto con las definiciones lexicográficas, se han incorporado el examen de iconografía y de fuentes literarias. El análisis sedetieneenalgunoshitosseleccionadosdentrodelaperiodización propuesta con el fin de señalar aquellos elementos que otorgan "encarnadura" al concepto estudiado.

El artículo es tributario de los estudios de historia conceptual que han surgido en los últimos años a partir de los trabajos del historiador Reinhart Koselleck. Siguiendo al autor, como señala Javier Fernández Sebastián, a diferenciadelaspalabraslosconceptosseríancomounasuertede"concentrados deexperienciahistórica"y'dispositivosdeanticipacióndelasexperienciasposibles"6.Es decirlosconceptossonhistoriapues"articulanlasexperienciasdeunasociedady lascambiantesexpectativasdesusmiembros" ${ }^{17}$.Enesecamino,aunquelahistoria conceptual ha centrado su trabajo en el análisis de los conceptos políticos fundamentales, estacomunicacióntieneencuentasusherramientasymeto-

5 FERNÁNDEZSEBASTIÁN,Javier.Elenfoquedeunahistoria deconceptosysuaplicación. EnCAETANO, Gerardo (coordinador). Historia conceptual. Voces y conceptos de la política oriental (1750-1870). Montevideo: Ediciones de la Banda Oriental, 2013. p. 17.

6 FERNÁNDEZSEBASTIÁN, Javier (director). Diccionario políticoysocial del mundo iberoamericano. La era de las revoluciones, 1750-1850, Iberconceptos I, Madrid: Fundación Carolina, Sociedad Estatal de Conmemoraciones Culturales, Centro de Estudios Políticos y Constitucionales, 2009, pp. 25- 26.

7 FERNÁNDEZ SEBASTIÁN, Javier; CAPELLÁN DE MIGUEL, Gonzalo. Conceptos políticos, tiempo e historia. Santander: Editorial de la Universidad de Cantabria, 2013, p. 13. 
dologías para el análisis de un concepto vinculado a la historia social y cultural del Río de la Plata. A partir de allí se propone el enfoque de la historia conceptual como un conjunto de herramientas de análisis que permitirían historiar el devenir de algunos conceptos que hacen a la conformación de las identidades de esta región. El tema de la imagen, los conceptos y en particular los monumentos no ha sido ajeno a algunos estudiosos de la historia conceptual como el propio Koselleck y Faustino Oncina ${ }^{8}$. Al mismo tiempo la diversidad de las fuentes a consultar exigen una mirada interdisciplinaria, consecuenciade"laomnipresenciadelosconceptosentodaslasáreasdelconocimiento yentodaclasedeescenariossocialesypolíticos" ${ }^{119}$ ademásdetratarsederepresentaciones que forman parte del patrimonioy las memorias de la región, aspecto que demanda el diálogo con diferentes ramas del conocimiento.

Influenciada por los trabajos ya mencionados, aunque no centrado en conceptos más allá de lo político, pero vinculado a los estudios de la historia conceptual, Ariadna Islas ha analizado el concepto de república a partir del examen de algunos monumentos ubicados en la ciudad de Montevideo ${ }^{10}$.

Más allá de la historia conceptual en los últimos años la historiografía ha avanzadoenlautilizacióndelasfuentesiconográficas,enelusodeestampas,pintura,fotografía,entreotrossoportes.Enparticularenlaregióneltemadelasimágenesdelospueblosamerindioshasidotambiénanalizadoporlahistoriografía.

La etnohistoriadora Martha Bechis en su artículo“Rostros ranquelinos... ¿rostrosranquelinos?eldibujohistóricoenproblemas"analizalacirculacióndealgunasimágenes sobrelos ranquelesen diversos medios dedivulgación en el último tercio del siglo XX y da cuenta de la forma en que fueron construidas.

8 KOSELLECK, Reinhart. Futuro pasado: para una semántica de los tiempos históricos. Barcelona: Paidos, 1993; ONCINA, Faustino. Koselleck y el giro icónico de la historia conceptual. Revista Anthropos: Huellas del conocimiento, $\mathrm{n}^{\circ}$ 223, pp. 71- 81, 2009.

9 FERNÁNDEZ SEBASTIÁN, Javier y CAPELLÁN DE MIGUEL, Gonzalo. Lenguaje, tiempo y modernidad. Ensayos de historia conceptual. Santiago de Chile: Globo Editores, 2011, p. 12.

10 ISLAS, Ariadna. Marianne no está sola. A propósito de la iconografía y el concepto de la república en la estatuaria en el Uruguay 1830-1930. Ponencia presentada en el Coloquio Internacional “El lenguaje político más allá de la política: hacia una historia de los conceptos sociales, culturales y jurídicos en los mundos ibéricos, siglo XVIII- XX", Casa de Velázquez, Madrid, 5-6 de setiembre de 2016. Agradezco a la autora el conocimiento de su trabajo. 
Rostros que alteran algunas de sus fisonomías, se cambia el sombrero y se "inventa" a un cacique. El artículo advierte la confusión que generan esas imágenes, las cuales incluso circularon en textos escolares ${ }^{11}$.

Regina Celestino de Almeida ha estudiado la producción de Jean Baptiste Debret sobre los indios del Brasil y sus imágenes de "civilizados" y"salvajes". La autora señala que dichas imágenes ilustran los mestizajes característicos de las sociedades de frontera, las formas de clasificar a los grupos socialesquehabitabanesosterritoriosylasconcepcionespolítico-ideológicas quepredominabanenlaAméricaportuguesa.Almismotiempolasimágenes de"Índiosemestiços,"selvagens"e"civilizados"interagiameconfundiam-senassociedadesamericanasenasimagenseclassificaçõesdoautor" ${ }^{\prime \prime 2}$.ElanálisisdeCelestinode Almeidaresulta deinterés cuando contrastalasimágenesylostextos deDebret, que dan cuenta de las confusas clasificaciones que sustentan su trabajo.

En el artículo referimos a múltiples textos, escritos e iconográficos. MereceunamenciónespecialeltrabajodeJoséJoaquínFigueira,EduardoAcevedo DíazylosaborígenesdelUruguay.Atravésdeunrecorridosistemáticoyprofundo de las fuentes en Montevideo y en el extranjero, Figueira rastrea la presencia de los "aborígenes del Uruguay"en diversas obras del escritor Eduardo Acevedo Díaz, y en las memorias de algunos contemporáneos con aquellos grupos indígenas como el coronel Modesto Polanco o el general Antonio Díaz, quienes dejaron vívidos relatos sobre los charrúas. Es de subrayar el esfuerzo del autor por rastrear las peripecias del grupo de cuatro charrúas llevados a Francia, tema que abordamos en páginas siguientes, donde Figueira da a conocer la mayoría de las "fuentes francesas" sobre el destino de aquellos indios. A la labor de Figueira debemos buena parte de la información sobre los "últimos charrúas" que hoy todos conocemos ${ }^{13}$.

11 BECHIS, Martha. Rostros ranquelinos... ¿ rostros ranquelinos? el dibujo histórico en problemas. Boletín Tefros, Río Cuarto, volumen 1, n० 2, invierno 2004, disponible en http://tefros.equiponaya. com.ar/revista/. Acceso 22 de julio de 2016.

12 CELESTINODEALMEIDA, Regina.Índiosmestiçoseselvagenscivilizados deDebret:reflexões sobrerelações interétnicas e mestiçagens. Belo Horizonte:Varia Historia, vol. 25, n 41, pp. 85 - 106, 2009.

${ }^{13}$ FIGUEIRA, José Joaquín. Eduardo Acevedo Díazy los aborígenes del Uruguay. 3 tomos. Montevideo: Estado Mayor del Ejército, Departamento de Estudios Históricos, División Historia, 1977. En particular en el segundo tomo el autor analiza el periplo de los "últimos charrúas". 
AnnieHouotenGuaraníesycharrúasenlaliteraturauruguayadelsigloXIX: realidadyficciónanalizaunenormecorpusdocumentalquerefierenaloscharrúasy guaraníesy da cuenta delas distintas valoraciones que de estosgrupos hicieron escritores, viajeros, naturalistas, intelectuales y políticos durante el siglo XIX. De la misma autora, es el libro Un cacique charrúa en Paris, que se centra en la peripecia del grupo de charrúas llevados a aquella ciudad por François de Curel y de las repercusiones en Europa ${ }^{14}$.

El trabajo de Houot se vale de los resultados de la paciente investigación deJoséJoaquínFigueira,quiendurantedécadasrecorrióarchivosuruguayosy extranjerosenbuscadetodoslos registrossobrelaperipeciadeaquelloscharrúas.Comoyasemencionó,Figueirafuequientomócontactoporprimeravez con losarchivos francesesy quien rastreó en la prensa periódicalasimágenes que circularon y hoy conocemos de los denominados "últimos charrúas"15.

Textos- imágenes de la voz"charrúas"

\section{en los inicios del Estado Oriental}

En los inicios de la vida republicana el Estado Oriental enfrentó múltiples desafíos, por ejemplo la inexistencia de límites territoriales, las dificultades para implantar una nueva fiscalidad, las tensiones entre tradiciones jurídicas de "antiguo régimen" y las ideas liberales y el peso de la guerra y los conflictos con los estados de la región. Al norte del Estado Oriental, los estancieros y las autoridades de la frontera demandaban medidas contra las tolderías de amerindios no reducidos. La presencia indígena para las autoridades era también un peligro por el temor a alianzas con las facciones que disputaban el poder ${ }^{16}$.

${ }^{14}$ Cf. HOUOT, Annie. Guaraníes y charrúas en la literatura uruguaya del siglo XIX: realidad y ficción. Montevideo: Editorial Linardi y Risso, 2007; HOUOT, Annie. Un cacique charrúa en Paris.

Montevideo: Imprenta y Editorial Costa Atlántica, 2002.

15 FIGUEIRA, José Joaquín. “El cacique charrúa Vaimaca Perú fue soldado de Artigas" en "Artigas", Suplemento diario Acción, Montevideo, 18 de junio de 1964. p. 30.

16 Para una versión actualizada de los inicios del Estado Oriental Cf. FREGA, Ana (coord.). Uruguay.Revolución, independenciayconstruccióndelEstado.Tomo1-1801-1880.Montevideo:Planeta, Fundación Mapfre, 2016. 
En los prolegómenos de la presidencia de la república de Fructuoso Rivera (1830-1834), los estancieros del norte del país demandaban una acción del nuevo estado en relación a las tolderías de "indios infieles". Los reclamos se vinculaban a los robos de vacunos, caballos y faenas de cueros que realizaban las tribus como parte de sus actividades comerciales. En ese contexto incluso llegaron a proponer al presidente correr con los gastos para fletar a los indios en una embarcación con destino a la Patagonia ${ }^{17}$.

En 1831 el presidente de la república, organizó una acción de exterminio contra las tolderías de indios no sometidos que habitaban al norte del río Negro. Este episodio, conocido como de "Salsipuedes", en alusión al lugar de la matanza ${ }^{18}$, exterminó a buena parte de los integrantes de las tolderías y concretóla desintegración de sus grupos, no solo a través de la muerte sino dela prisión forzaday del cautiverio que padecieron muchos delos quecayeron prisioneros. En relación con el cautiverio, predominó la incorporación al personal de servicio de familias acomodadas de Montevideo, así como algunos repartos en familias del interior del país ${ }^{19}$.

Desde la colonia los charrúas estuvieron asociados al concepto de"salvajes" " "indios infieles". Esta caracterización era en alusión a no estar sometidos ni bajo reducción en pueblos de indios. Tal como lo señala David J.Weber, las poblaciones indígenas en América, ubicadasmás allá delos dominios españoles, fueron caracterizadas porlasautoridadescolonialescomo"indios bravos", "bozales", "infieles", "gentiles salvajes"y "bárbaros"20. Los"salvajes" e "infieles" fueron los habitantes del "desierto", un problema para los grandes

17 HOUOT, Annie. Op. Cit., Un cacique charrúa en Paris..., p. 5.

${ }^{18}$ En el departamento de Tacuarembó, el arroyo Salsipuedes Grande, es un afluente del río Negro.

19 Al respecto: ACOSTA Y LARA, Eduardo F. La guerra de los charrúas. Montevideo:Talleres de Loreto Editores, 1998; PADRÓN FAVRE, Oscar. Sangre indígena en el Uruguay. Montevideo: Editorial Barreiro, 1987; PI HUGARTE, Renzo. Historias de aquella "gente gandul". Españoles y criollos vs indios en la Banda Oriental. Montevideo: Editorial Sudamericana Uruguaya y Editorial Fin de Siglo, 2005. CABRERA, Leonel; BARRETO, Isabel. El ocaso del mundo indígena y las formas de integración a la sociedad urbana montevideana. Revista TEFROS, Río Cuarto, Vol. 4 №2, Primavera de 2006.

20 WEBER, David J. Bárbaros. Los españoles y sus salvajes de la era de la ilustración. Barcelona: Editorial Crítica, 2007. p.34. 
propietarios de tierras y el desvelo de la administración colonial ${ }^{21}$. Aunque hemospresentadoelasuntodemanerasintética,existeunacontinuidadenla forma de referir a esos grupos que se remonta a los tiempos coloniales.

Enelmarco del proceso deconstrucciónestatal einserción internacional como país productor de materias primas, fue necesario para el gobierno alcanzar el control de todo el territorio. Al igual que durante la colonia, los propietarios de tierras fueron uno de los sectores principales en presionar al gobierno para buscar "soluciones" al "problema indígena". Luego del episodio de Salsipuedes, el presidente Rivera escribió al Comandante de la Colonia del Cuareim ${ }^{22}$ acerca del éxito de la campaña. En la correspondencia caracterizóaloscharrúascomo"hordasalvaje","indómita"y"puñadodebandidos"23. Otro funcionario, el general Julián Laguna, quien tenía campos ocupados por tolderías de amerindios, utiliza los mismos calificativos al comunicarse con el Jefe del Estado Mayor para informarle acerca de las medidas que se llevabanadelante"paraexterminarlossalvajesqueinfestanelterritoriodelEstado"24.

La necesidad de instalar el "orden" en la campaña era anterior a la creación del Estado Oriental. Gauchos, indios, hombres sueltos y vagos eran una amenaza a esa aspiración. Las medidas tomadas por el primer presidente constitucional del país, apoyadas por la élite gobernante, se relacionaban al "orden" que el nuevo estado debía implantar. El exterminio de los indígenas era,segúnRivera,"unamedidanecesariaal «ordenpúblico»”25.Comoseñalala historiadora Ana Ribeiro:

"El orden debía avalar la existencia de un deber ser nacional; el desorden, por lo tanto, podía poner en riesgo la reciente independencia. La vozindependen-

${ }^{21}$ Al respecto DÁVILA, Adriana; AZPIROZ, Andrés. Indios, cautivos y renegados en la frontera. Los blandengues y la fundación de Belén 1800- 1801. Montevideo: Ediciones Cruz del Sur, 2015.

22 La Colonia del Cuareim estaba integrada por habitantes procedentes de los pueblos misioneros luego del abandono de esos territorios por la fuerza de Rivera en 1828.

${ }^{23}$ Fructuoso Rivera al Comandante de la Colonia del Cuareim, Bernabé Magariños. Salsipuedes, 15 de abril de 1831 en ACOSTA Y LARA, Eduardo F. Ob. Cit., 2da parte, p. 85.

24 Julián Laguna al Jefe del Estado Mayor, Paysandú, 30 de julio de 1831 en ACOSTA Y LARA, Eduardo F. Ob. Cit, 2da parte, p. 90.

${ }^{25}$ RIBEIRO, Ana. Ordeny desorden:saludy enfermedad social en tiempos de heroísmos fundacionales. En CAETANO, Gerardo. Ob. Cit., p. 124. 
ciasearticulóentonces con orden, tambiénconel significado debiencolectivo adquirido en el trayecto histórico que los convirtió en nación"26.

Alcanza con revisar otros documentos y advertir que se reitera la caracterización de los charrúas como"horda salvaje". En 1853 el Diccionario de Ramón Joaquín Domínguez, la definía de la siguiente manera:

“Tribu errante, conjunto de familias nómades, sin domicilio fijo, comolas delos beduinos, lasdelostártarosindependientes, olasdelossalvajes, queaborrecen todo lo que tiende a civilizarlos o a restringir su apetecible independencia"27.

Fructuoso Rivera ya había comparado a los charrúas con otras tribus de "salvajes", como los beduinos. En efecto en una nota enviada el 25 de agosto de 1824 al Barón de la Laguna, Rivera, usando un lugar común de los modelos de barbarie, señala la necesidad de llevar adelante métodos de reduccióndeloscharrúas,pues"noposeenmástácticaqueladelbeduino"y,por elcontrario,tienenasufavor"supropiapequeñez,ysumovilidadextrema,sobreun terreno conocido" 28 .

En 1832, François de Curel ${ }^{29}$, director del Colegio Oriental de Montevideo, conocedor de los problemas que causaban para el estado el manteni-

${ }^{26}$ Ibídem.

27 DOMÍNGUEZ, RAMÓN JOAQUÍN. Horda. En: Diccionario Nacional o Gran Diccionario Clásico de la Lengua Española (1846-47). Madrid-París: Establecimiento de Mellado, 1853, 5 a edición. 2 vols, disponible en: rae.es/ntlle

${ }^{28}$ Fructuoso Rivera al Barón de la Laguna, 25 de agosto de 1824, en ARCHIVO GENERAL DE LA NACIÓN, Buenos Aires. Sala VII. Colección Carlos Casavalle, N²309, Documentación general, Legajo 7, 1819-1826, f. 479-180. Debo el conocimiento de esta versión a Ana Frega. Una versión casi idéntica se encuentra en la papelería del capitán de blandengues Jorge Pacheco, depositada en el Archivo General de la Nación en Montevideo. Aunque todavía no hemos confirmado la autoría de la misma, seguramente haya sido escrita por algunos de los asesores de Pacheco y luego manejado el proyecto por Fructuoso Rivera. Al mismo tiempo da cuenta del mantenimiento de algunas visiones sobre los indígenas que venían, por lo menos, desde principios del siglo XIX.

${ }^{29}$ François de Curel se había desempeñado como capitán del Estado Mayor agregado al Ministerio de Defensa de Francia y como inspector del colegio Henri IV de París. Luego pasó a Buenos Aires, ciudad queabandonó por problemas económicos, para pasara Montevideo dondeestableciójunto a su esposa, Marie Louise, el Colegio Oriental. Sobre la actuación del matrimonio Curel en el 
miento de los indios presos luego de las acciones de exterminio, presentó un proyectopara"llevarconél[aParis]cuatroindioscharrúasconelobjetodepresentarlos aS.M.elreydeFrancia,alasSociedadesCientíficasyotraspersonasdedistincióneilustración". Curel prefería llevar a los caciques Brown y Perú, y estaba a favor de que el gobierno eligiera dos indias para integrar el grupo. Luis Lamas, jefe de policía de Montevideo, realizó un informe favorable, manifestó su acuerdo conelofrecimientoyseñalólaconveniencia“dequeenlugardePerú,lofueraLaureano[Tacuabé],porserestejovencomode20añosyunmalvadoqueconvendríaalejar delPaís,yporelcontrarioaquélunancianopacíficoymoderadoensuscostumbres" ${ }^{\prime \prime 30}$.

El 25 de febrero de 1833 embarcaron a Francia cuatro indios charrúas, tresvaronesyunamujer.Elloseran“losindiosLaureano,Perú,SenaquéyMicahela [Guyunusa]". Junto con Curel iba Arthur Onslow, un pintor y dibujante francés, ex-socio de Hipólito Bacle en su Litografía del Estado, establecida en Buenos Aires. De unos años atrás son sus dibujos del“Traslado del cadáver delGobernadorManuelDorrego",impresoen 1829,elretratodeJuanManuelde Rosasy los primeros dibujos de la serie de litografías de"Tragesy Costumbres delaProvinciadeBuenosAires", publicadasen 1830.Enagostode1831Onslow pasóa Montevideo donde, además dedesarrollarsu trabajocomo dibujante, dictó clases en el Colegio Oriental dirigido por el matrimonio Curel.

¿De qué manera la iconografía representó a los indios llevados a Francia? Existen dos grabados que representan al grupo decharrúas. Veremoslos contrastes entre uno y otro.

Arthur Onslow realizó un dibujo de los indios que luego fue reproducido en una litografía. La imagen acompañaba un folleto que Curel utilizó en Francia para promocionar las visitas a su zoológico humano. La litografía se titula"Indiens Charruas"y en ella aparece al centro la imagen del caciqueVaimaca Perú, apoyado sobre su arco de flechas, vistiendo un quillapí de piel de "jaguar" decorado con dibujos geométricos. Vaimaca lleva un cinturón del quecuelgan unas boleadoras. El rostroy el porte dan cuenta de sus atributos

Colegio Oriental en Montevideo:Cf. ARAÚJO, Orestes. Historia de la escuela uruguaya. Montevideo: El Siglo llustrado, 1911. p. 183 - 184.

${ }^{30}$ Carpetas y notas varias de Francisco de Curel relativas a la conducción de un grupo de Charrúas a Francia en ACOSTA Y LARA, Eduardo F. Ob. Cit, p. 109. 
como jefe del grupo. A su derecha están Micahela Guyunusa y Tacuabé, ambos sentados, y a diferencia de lo que señalan muchas fuentes en relación a su vestimenta, están ataviados con prendas ricamente ornamentadas. A la izquierda de Vaimacá está Senaqué quien viste el mismo tipo de manto y sostiene un mate en su mano.

En el folleto donde se reproducía la imagen se señalaba:

“El primero es un cacique temible [Perú]; el segundo [Senaqué], uno de los por ellos denominado médico, que tiene la pretendida ciencia de la magia médi$\mathrm{ca}$, añadiendo realmente el conocimiento de simples adecuados para curar las heridas. El tercero es un joven y bravío guerrero [Tacuabé], reconocido por su destreza para domar caballos salvajes; el cuarto [Guyunusa], una mujer, es la compañera del joven guerrero" ${ }^{\prime \prime 1}$.

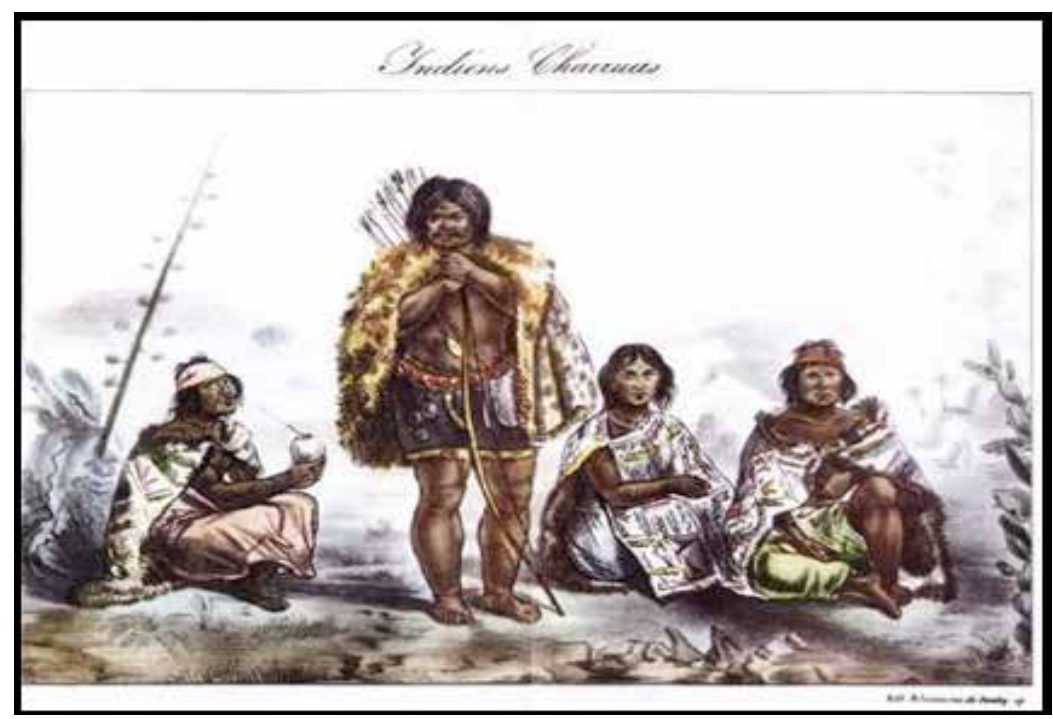

Imagen I

Arthur Onslow, Indiens Charruas, c. 1833, litografia.

${ }^{31}$ RIVET, Paul. Los últimos charrúas. Montevideo: Ediciones de la Plaza, 2003, p. 35. 
En el exterior Curel promovía el exotismo de sus prisioneros. Acentuaba sus características como indios de armas y apelaba incluso a sus creencias mágicas.Un medio deprensafrancés, LeTemps, afirmabaluegodela inauguración de la "exposición" realizada el 8 de junio de 1833 los mismos conceptos promovidos porCurel en su folleto de propaganda ${ }^{32}$. El periodista se refería a los charrúas como "salvajes", idea fortalecida por la escenificación que François Curel, seguramente con la ayuda de Onslow, habían preparado:

“Lossalvajesestáncasidesnudos.Seencuentranagrupadosalrededordeunfogón enelqueasanlacarnefrescaquelessirvedealimento.Parecíanestaralgorecelosos porla presencia dequinceaveinteextranjeros.Sin embargo, ellos sefueron familiarizandorápidamente,ycomohablan bastantebienelespañolyelportugués, pudieron responderalaspreguntasqueleshicieronalgunosvisitantes"33.

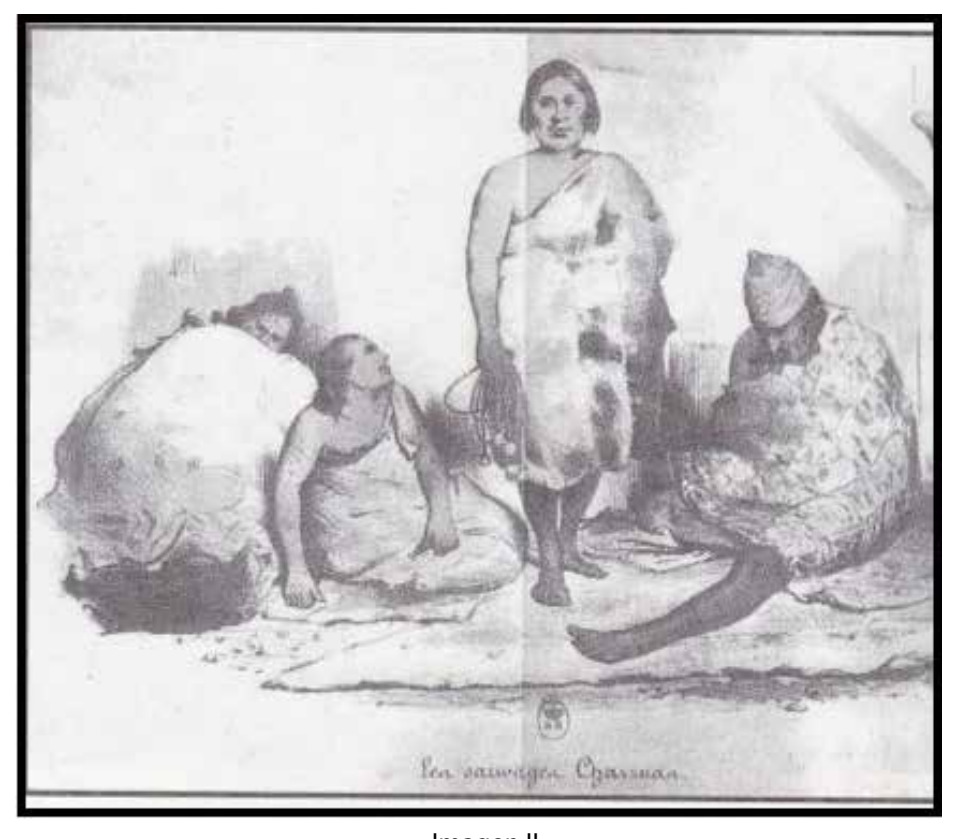

Imagen II

Bernard. Les sauvages charrúas, c. 1833, xilografía.

32 Ibídem, p. 37.

33 Ibídem, p. 39. 
A diferencia del dibujo de Onslow, la xilografía que acompañó una columna periodística de L. Gozlan sobre los charrúas en Paris en Le Musée des Familles, representa un grupo de personas abatidas ${ }^{34}$. Ninguno de los indios viste atuendos profusamente decorados, sino que por el contrario sus vestimentas son sencillas y andrajosas. Vaimaca, Ileva un cuero vacuno por único vestido, y ostenta simplemente, unjuego de boleadoras. Por el contrario, Senaqué, Guyunusa y Tacuabé dan una imagen de grave deterioro físico y enfermedad.Dehecho, sabemosqueSenaquéseenfermódeuna“fiebredeconsunción"ocasionadapor'ladesesperanza,eltedio,ysobretodo[sic],lanostalgia".Por ese motivo, el Museo del Hombre de París decidió invertir parte de los fondos "destinadosalaadquisición deanimalesraros"alpagodelosgastosmédicos ${ }^{35}$.

Ambasimágeneshacenhincapiéenelexotismodelgrupo,asociándolos a la idea de "indios salvajes" y "guerreros", apelando a una escenificación que fortalece esos conceptos. Las imágenes deben ser vistas en pares para advertir la oposición del esplendor de los charrúas con la representación de un cautiverio opresivo.

La exhibición tuvo eco en Montevideo. La oposición entre lo “salvaje”y lo "civilizado" fue realizada por el coronel Antonio Díaz, fundador y director de El Universal, quien al dar cuenta de la "exhibición" de los indios charrúas en Paris, opuso a aquellos "salvajes" con los habitantes "de un pueblo el más llustrado de la tierra" ${ }^{36}$ :

\begin{abstract}
"no dejará de interesar al observador de la naturaleza el contraste que debe ofrecer el cuadro material de su primitivo estado representado en los cuatro Indígenas, con el estado presente del hombre social, en un punto que reúne todos los elementos de la civilización y que va delante de todos los pueblos en los progresos del espíritu humano. Asíla morada del Indio Perú envuelto en un Quillapí y devorando un pedazo de carne medio cruda en los campos Eliseos, y por otra parte el Gabinete de la Academia de las Ciencias en París forman los dos puntos extremos en la larga cadena de la historia del hombre en socie$\mathrm{dad}^{\prime \prime 37}$.
\end{abstract}

\footnotetext{
${ }^{34}$ HOUOT, Annie. Ob. Cit., p. 24-25.

35 Ibídem, p. 43.

${ }^{36}$ Montevideo, El Universal, 16 de octubre de 1833, p. 2. Agradezco a Ariadna Islas esta referencia.

37 Ibídem.
} 


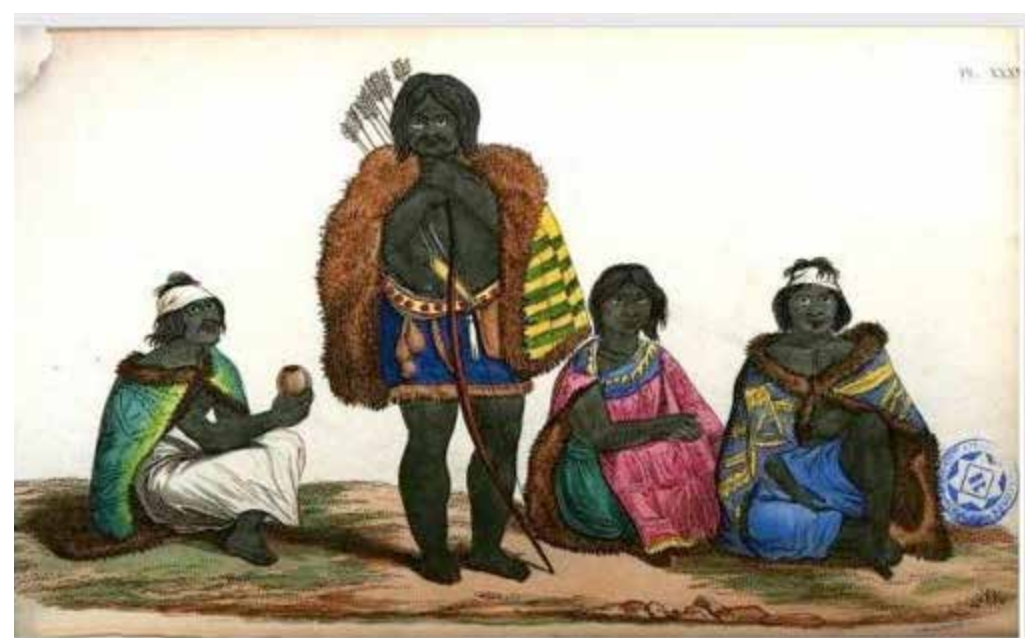

Imagen III

Una imagen muy similar a la atribuida a Arthur Onslow fue publicada en 1843 en la Histoire naturelle de l'homme por el médico James Cowles Prichard $^{38}$, integrante de las academias de medicina de Londres y Francia. En su historia natural, en la que menciona a "todas las razas", Prichard incluye a los charrúas dentro del grupo de la "raza pampeana", junto a patagones, abipones y tobas; señala que han sido exterminados de la "Banda Oriental y Entre Ríos" y que son "más negros que los mulatos", aspecto que, según señala, es bien recogido en la imagen que incorpora a su texto ${ }^{39}$.

Otra representación contemporánea de los "indios charrúas" es la de Jean Baptiste Debret, quien los representa en dos imágenes opuestas: los charrúas civilizados y los charrúas salvajes. Debret viajó a Brasil en 1816 comointegrantedeladenominada"MisiónArtísticaFrancesa"incentivadapor

\footnotetext{
38 PRICHARD, James Cowles. Histoire naturelle de l'homme.Tomoll. Paris:Chez J. Bailliere, 1843. p. 204.

39 Ibídem, p 205.
} 
João VI ${ }^{40}$. En 1827 visitó el sur de Brasil, desde San Pablo a Río Grande del Sur, pasando por Santa Catarina y Paraná ${ }^{41}$. A su regreso a Francia, publicó entre1834y 1839, tresvolúmenesdelitografíastituladas“VoyagePittoresqueet HistoriqueauBrésil,ouSéjourd'unArtisteFrançaisauBrésil".En“Charruascivilisés", asocia a los indios "civilizados" con "peones" de estancia y los representa en el medio de un ámbito de trabajo rural. Los "charrúas"tienen atributos de su cultura, pero también hay huellas del mestizaje, de las formas de asimilación que se hacen evidentes en la vestimenta, ataviados como los criollos, a lo que se suman las boleadoras, el lazo, las espuelas, las botas de potro, los sombreros y un cuero de algún animal salvaje, utilizado como bolsa.

Como señala el investigador brasileño Anderson Ricardo Trevisan, la representación de los charrúas conserva aspectos de la cultura indígena (las boleadoras, el uso de pieles de animales salvajes yel color dela piel) que otorgan a la imagen un carácter simbólico, resultando una escena "deseable" de los "salvajes"42. La publicación del álbum de J. B. Debret coincide en el Río de la Plata con la construcción de los estados nacionales, asociadoal proceso de inserción internacional del país y los intentos por consolidar los derechos de propiedad privada en el medio rural. En ese contexto, el charrúa civilizado (como sinónimo de fuerza de trabajo rural) es la alternativa al exterminio.

Para Ariadna Islas, la voz "civilización" tiene entre sus acepciones una que refiere a un estado evolutivo de la humanidad o a un pueblo. El término es usado por sectores letrados -Debret forma parte de ese sector-y sobre todo en documentos destinados a la formación de opinión ${ }^{43}$. Como señala Islas.'Lacivilizaciónresultabaelefectodelaconversióndelaspasionesaefectos'civiles'

40 HOLANDA,SergioBuarquede.Oprocessodeemancipação.In:___ (org)Historiageraldacivilizaçãobrasileira. Tomo Il: o Brasil monárquico. Vol 1: O processo de emancipação. San Pablo: DIFEL, 1985. p. 119

${ }^{41}$ BANDEIRA, Julio; CORREA DO LAGO, Pedro. Debret e o Brasil: obra completa,1816 - 1831.

Río de Janeiro: Capivara. p. 63.

42 TREVISAN, Anderson Ricardo. Velhas imagens, novos problemas: a redescoberta de Debret no Brasil modernista (1930-1945), Tese de Doutorado em Sociologia, Programa de Posgraduación en Sociología. Universidade de São Pablo, 2011. p. 251.

43 ISLAS, Ariadna. Morigerar las costumbres para formar la nación. El concepto civilización en el discurso político desde la formación de la sociedad colonial hasta la constitución de la república (1750 - 1870). En CAETANO, Gerardo. Ob. Cit. p. 95. 
enmarcadosenlaley,adjetivopuesaplicadoalalibertad,algobiernoyalgobiernoindividualdesímismo,alcomportamiento,alaconducta" ${ }^{\prime 4}$.Comohemosseñaladolos primeros gobiernos del Estado Oriental buscaron "civilizar", tomando entre otras medidas las que se vinculaban al mantenimiento de la "paz social", donde el exterminio de los charrúas representaba la opción más "segura", a la concreción de la estabilidad del nuevo estado.

En oposición a los "charrúas civilizados", hacia 1834 Debret publicó la litografía "Chef de charrúas sauvages"donde representa a un "indio charrúa" semidesnudo, blandiendo una lanza y montado sobre un caballo de gran porte. Es la imagen de un guerrero y esa es la actitud en la que se encuentra el personaje. La imagen afirma el carácter "bárbaro" acentuado con la presencia de un paisaje agreste, también "salvaje", que se opone al contexto de la otra imagen donde los amerindios realizan tareas rurales. Al mismo tiempo en este caso se acentúan los atributos propios de una cultura indígena, el cacique monta sobre una piel dejaguarya excepción de las riendas no utiliza mayores elementos de la equitación europea.

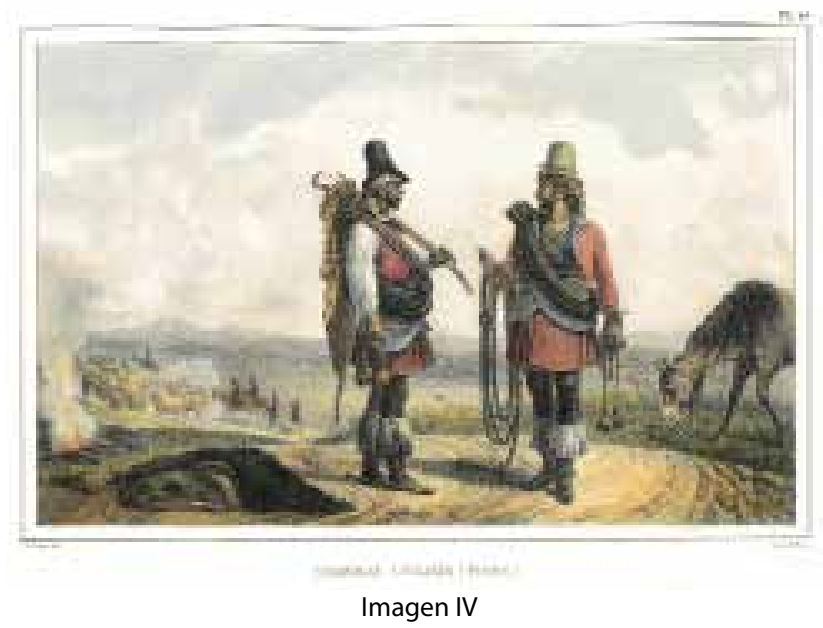

Uruguay, MHN-Casa de Lavalleja, Colección Pablo Blanco Acevedo, carpeta IX. Lámina N³3.“Charruascivilisés(Pions)".DibujodeJBDebret.LitografíadeCMotte.LáminaN15 delálbumdeDebret.

${ }^{44}$ Ibídem, p. 102. 
Hemosdadocuentadecuatroimágenesrealizadasporeuropeos,lasque circularon al menos en Francia en la década de 1830 y 1840. Los charrúas de Curel acentuaban el carácter exótico y guerrero de los indios. La litografía deDebret, aunqueincluyeelementos propios delacultura indígena, refierea unaimagen"deseable"deesosindios. Ambasimágenesconstruyen modelos del estereotipo de salvaje y civilizado.

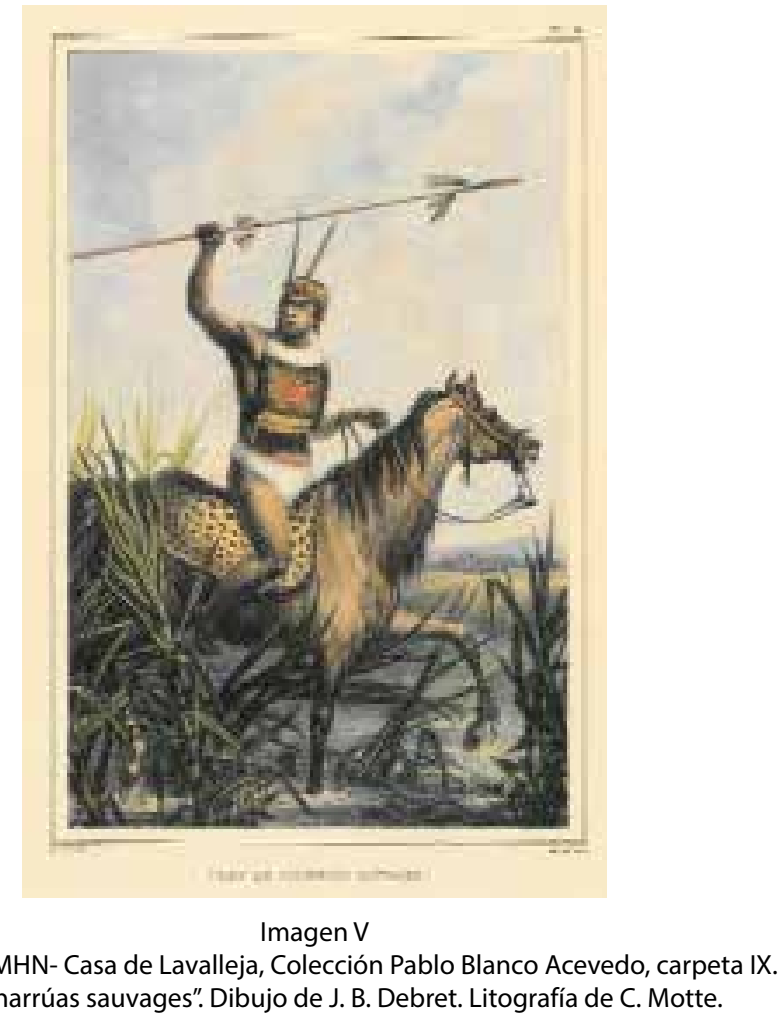

En 1832 Bernabé Rivera, familiar del presidente de la República Fructuoso Rivera, falleció en un combate contra un grupo de "indios charrúas" en el potrero de Yacaré-Cururú, al norte del Estado Oriental. Su muerte causó gran repercusión en la opinión pública y en el elenco de gobierno, lo 
cual influyó para acentuar la imagen que se tenía de los charrúas. Como homenaje a Bernabé y dedicado a Fructuoso Rivera, el poeta Francisco Acuña deFigueroaescribióun“Epicedioocanciónfuneral.Alaheroicamuertedelbravo coroneldonBernabéRivera",transcriptoeilustradoporel pintorycalígrafoJuan Manuel Besnes e Irigoyen en $1833^{45}$.

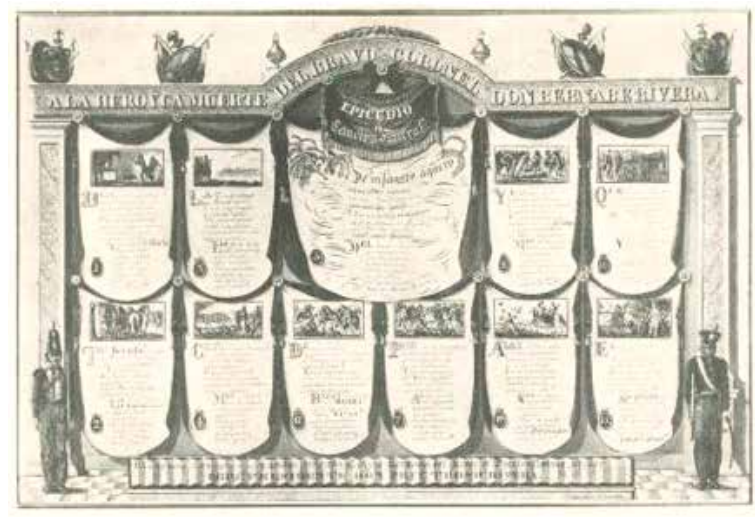

Imagen VI

MHN, Casa de Fructuoso Rivera, "Epicedio a la heroica muerte del bravo coronel don Bernabé Rivera", Francisco Acuña de Figueroa, Juan Manuel Besnes e Irigoyen, 1833, 101 x 66 cm.

El poema de Acuña de Figueroa ${ }^{46}$ opone el carácter heroico de la campaña comandada por Bernabé Rivera, la cual está asociada al progreso del país, con la barbarie de las tribus charrúas. Al igual que las ideas que fundamentan el exterminio de los charrúas, Acuña deFigueroa entiende que estos amerindios representan todo lo que el país debe abandonar para dar lugara una nueva etapa.

${ }^{45}$ MHN, Casa de Fructuoso Rivera, “Epicedio a la heroica muerte del bravo coronel don Bernabé Rivera", Francisco Acuña de Figueroa, Juan Manuel Besnes e Irigoyen, 1833, 101 x 66 cm. Un epicedio es una composición poética donde se llora y alaba a una persona.

${ }^{46}$ Un análisis del trabajo de Acuña de Figueroa y Besnes e Irigoyen en CARÁMBULA DE BARREIRO,Margarita.AlaheroicamuertedelbravocoroneldonBernabéRivera. RevistaHistórica,Montevideo, Tomo XVI, pp. 491 - 503, 1949. 
Hasta donde conocemos, esta ilustración de Besnes e Irigoyen al epicedio es la primera imagen producida en el territorio oriental sobre los indios charrúas y su representación no tiene como objetivo la verosimilitud sino la de representar un modelo del salvaje.

El epicedio está dividido en once escenas, donde se destacan diversos aspectosdelavidadelmilitarencontraposiciónconcaracterísticasnegativas de quienes lo mataron:

"Tu Bernabé, tú eras / el Numen de bondades,/ y entre dos tempestades/ el Iris tutelar./ Los barbaros levantan / el pendón parricida / y a la Patria afligi$\mathrm{da} /$ pretenden devorar" ${ }^{\prime \prime 7}$.

En el poema los indios charrúas son definidos como "salvajes", "hordas terribles",'"cometasdemuerte",'fieras"y"'monstruos".Peroesenlaescenaoctava donde se señala un aspecto que, años más tarde, será el que negarán los "idealizadores" de los charrúas: Besnes e Irigoyen representa el momento posterior a la muerte de Rivera, quien yace en el suelo. En el verso, Acuña de Figueroa introduce el tema de la antropofagia al caracterizar a los charrúas como "caribes":

"Ya al cadáver osados/ se acercan con fiereza. / le contemplan... y empieza / la escena del furor:/ No, no triunféis caribes, / que aún le resta un hermano / y en cada Ciudadano/ un suyo vengador" 48

El término "caribes" apareció por primera vez en un diccionario de lengua española en 1786. El diccionario de Esteban Terreros y Pandos, publicado en Madrid, definía"caribes" como sinónimo de "cannibales", en referencia directaa"algunoshabitadores delasIslasAntillas"49. Undiccionario de 1853 lo

\footnotetext{
47 Ibídem, escena 1.

48 Ibídem, escena 8.

49 TERREROS Y PANDO, ESTEBAN DE. Cannibales o caribes. En Diccionario castellano con las voces de ciencias y artes y sus correspondientes en las tres lenguas francesa, latina e italiana [...]. Tomo primero, Madrid, Viuda de Ibarra, 1786. Disponible en: rae.es/ntlle
} 
vinculabaal concepto de"crueleinhumano"pueslos caribes devorabana sus prisioneros y practicaban la poligamia ${ }^{50}$.

En 1835, durante la presidencia de Manuel Oribe, se inauguró el Cementerio Central. El gobierno encargó al marmolista Louis Dunand, autor devariostrabajosparael"Panteóndelosciudadanosmeritorios"enelcementerio de la recoleta en Buenos Aires, el sarcófago para los restos mortales del coronel Bernabé Rivera. Junto con este monumento funerario se inauguró una lápida doble, obra del marmolista J. Noble, dedicada a los soldados Pedro Bazán y Roque Viera, quienes murieron junto a Rivera. Los dos monumentos, encargados por el gobierno de Oribe, eran un reconocimiento a los soldadoscomo"defensores dela patria".LalápidadeRiveraestágrabadaconuna leyenda con ideas similares a las de la canción fúnebre de Acuña de Figueroa:

"Yndigena salvaje! indómito habitador de los / desiertos! He aquí tu víctima! Erizado tu cabello/Y cubiertos tus miembros de un sudor frío, ven, $y /$ temblando lancese de tu pecho el fúnebre alarido/ del dolor con más fuerzas que allá al inmolarlo/ lanzaste el horrible grito de la carnicería" ${ }^{51}$

\section{Los indios charrúas en la palabra y el papel}

En 1853, el Sargento Mayor de Caballería, Pedro Pablo Bermúdez publicó su obra teatral en verso "El Charrua"52. La presentación en el Teatro Solís de Montevideo en 1858, por partedela compañía de teatro española de Matilde Duclós ${ }^{53}$, generó una encendida polémica recopilada por la prensa

${ }^{50}$ [GASPAR Y ROIG]. Caribes. En___ Biblioteca llustrada de Gaspar y Roig. Diccionario enciclopédico de la lengua española, con todas las vozes, frases, refranes y locuciones usadas en España y las Américas Españolas, Tomo I, Madrid, Imprenta y Librería de Gaspar y Roig, editores, 1853. Disponible en: rae.es/ntlle

51 Cementerio Central de Montevideo, Panteón y sarcófago Bernabé Rivera.

52 BERMÚDEZ, PedroP.“EICharrúa”.'Drama histórico en verso. Montevideo:Imprenta deEl Orden, 1853.

${ }^{53}$ La actriz y empresaria de compañías de zarzuela, Matilde Duclós arribó a Montevideo alrededor de 1856. En 1857 presentó la obra La locura de amor, sobre la vida de Juana I de Castilla. Cf. FORNARO, Marita; SALOM, Marta; CARREÑO, Graciela y otros. Presencia e influencia española enelTeatroSolís deMontevideo(1856-1930):zarzuelas, sainetes, cupleterasy tangos. Cuadernos de Música Iberoamericana, s/d, vol. 13, 2007. pp. 7-8. 
acerca de la identidad y el lugar de los "charrúas" en la "historia nacional". La obra de Bermúdez ha sido ya analizada por Annie Houot ${ }^{54}$.

Pedro Pablo Bermúdez (1816-1860), hijo de un oficial de las fuerzas de José Artigas, inició la carrera de armas en 1832 cuando se integró al batallón deinfanteríadelíneadondealcanzóelgradodesubteniente.Alañosiguiente, pasó a la Fiscalía Militar hasta 1834 que pidió su pasaje a la caballería, revistando en el Regimiento No4. En 1836, luego de la batalla de Carpintería que significó una derrota para lasfuerzas deFructuoso Rivera, Bermúdezfue promovidoydistinguidocomo"beneméritodelapatria".En1837alcanzóelgrado de Sargento Mayor. Cuando la dimisión de Manuel Oribe en 1838, Bermúdez, al igual que otros militares, fue dado de baja del ejército. En ese momento decidió emigrar a Buenos Aires, lugar en el que permaneció hasta $1842^{55}$.

En esos años escribió su primer borrador deEl Charrúa, el cual surgió"en unaconversacióndesobremesayporunrasgodeamorpropio".Bermúdez"orientalydesterrado",decidióescribirundramahistóricosobreloscharrúas, pues:"Puestas misideasenmovimiento,recorrieronaprisanuestraviejahistoria"y'Enellavilevantarse la raza belicosa dueña de los campos $[\ldots]^{\prime \prime 56}$.

Bermúdez regresó al Estado Oriental en 1842 como integrante del Ejército Unido de Vanguardia de la Confederación Argentina bajo la jefatura de Manuel Oribe. A partir de la instalación del denominado Gobierno del Cerrito, durante la Guerra Grande, Bermúdez residió alliín . Luego de la batalla de Monte Caseros (1852) se incorporó a la Comandancia General de la 2da sección para pasar a la Guardia Nacional y a la Comandancia militar

${ }^{54}$ Para un análisis de El Charrúa, Cf. HOUOT, Annie. Guaraníes y charrúas en la literatura uruguaya del siglo XIX: realidad y ficción. Montevideo: Editorial Linardi y Risso, 2007. pp. 287 y ss. ${ }^{55}$ FERNÁNDEZ SALDAÑA, José María. Ob. Cit., p. 179-181.

${ }^{56}$ BERMÚDEZ, Pedro P. Ob. Cit., p. II.

57 Se conoce como Guerra contra Rosas o Guerra Grande al conflicto bélico que se extendió entre 1838 y hasta 1852 cuando la derrota de Juan Manuel de Rosas en la batalla de Monte Caseros. Se trató de un conflicto de carácter regional e internacional que involucró a las potencias europeas como Francia e Inglaterra. A partir de 1843 en el Estado Oriental, dos gobiernos se auto denominaron como legítimos, por un lado el de la defensa bajo la conducción de Joaquín Suárez y por otro el instalado en las afueras de Montevideo, en el Cerrito, presidido por Manuel Oribe. Mientras los partidarios de Oribe recibieron el apoyo de los federales de Rosas, el gobierno de Montevideo fue respaldado por los unitarios y por las fuerzas extranjeras. 
posteriormente. En ese momento reescribió El Charrúa, ya que su borrador original se había traspapelado. Durante la presidencia de Gabriel Antonio Pereira (1856-1860) prestó servicio comoedecán hasta 1859 cuando se hizo cargo, hasta su muerte en 1860, de la Jefatura Política de Montevideo.

Aunque el caso de Bermúdez no es el de un intelectual, la lectura de su obra advierte de una cierta formación libresca acumulada, sobre todo vinculada a la lectura de diversos cronistas de América e historias del continente que circulaban en el siglo XIX. Como señala el historiador Juan Antonio Oddone, el drama histórico de Bermúdez, como representante de la producciónversificadadelos"poetasdelsentimientopatrio",promovióunaveneración del pasadoapelandoaloselementosprimarios"conlafinalidad deerigirlosen estandarte de la regeneración nacional" 58 .

En la edición original de 1853 se acompaña la primera página con la opinión del poeta Francisco Acuña de Figueroa. En verso y brevemente, el poeta felicita la obra de Bermúdez:

"Apruebo como Censor,

Y aplaudo como Oriental,

Al Charrúa, y a su autor;

Y ambos logren prez, $y$ honor.

En el teatro nacional" ${ }^{159}$.

Sin embargo, El Charrúa se distancia de las palabras de Acuña de Figueroa en el epicedio. En su "drama histórico", que acompaña de una serie de notas y evidencias documentales, Bermúdez asume una defensa de esta tribu $^{60}$, la cual se desarrolla en el marco de los debates sobre el americanismoy la identidad, consecuencia delas intervenciones europeas durantela Guerra Grande $^{61}$. El drama se ambienta en el siglo XVI en un espacio que para el

58 ODDONE, Juan Antonio. La historiografía uruguaya en el siglo XIX. Apuntes para su estudio. Revista Histórica de la Universidad, Montevideo, segunda época, n 1, 1959. p. 6.

59 BERMÚDEZ, Pedro P. Ob. Cit., p. 1.

60 "Yo canto al ínclito esfuerzo/ De la jigantezca raza, / Que hiciera trescientos años / Pie firme, frente a la España,/ Llevando diversa suerte / A diferentes batallas/"Bermúdez, Pedro P. Loc. Cit.

${ }^{61}$ WASSERMAN, Fabio. Entre Clío y la Polis. Conocimiento histórico y representaciones del pasado en el Río de la Plata (1830-1860). Buenos Aires: Editorial Teseo, 2008. p. 125. 
autorya es habitado por ese grupo indígena, territorio que está unido, desde ese momento, a la "patria".

La historia narrada por Bermúdez tiene su origen en la crónica de Martín del Barco Centenera publicada en $1602^{62}$. Sin embargo, Bermúdez hace algunas adaptaciones con el objetivo de acentuar el protagonismo de los charrúas. En el drama se narra el suicidio de una pareja de charrúas, Abayubá y Lirompeya (sic), frente al temor de ser separados por su captor, el capitán español Carvallo.

Como ya señalamos, el drama histórico de Bermúdez va acompañado de notas aclaratorias. Se destacan dos precisiones realizadas por el autor sobre aspectos que hacían a la "mala prensa" de los indios charrúas: sus cultos mágicos y sus prácticas antropofágicas.

En relación a las prácticas mágicas, aunque el autor reconoce sus cultos religiosos, la argumentación asume la idea del "buen salvaje” y reclama, al final, una mirada de "justicia" como ha ocurrido con otras tribus indígenas del norte de América ${ }^{63}$.

Sobre la antropofagia, la aclaración se vincula a la necesidad del autor de despejar la idea de que los charrúas la practicaron con Juan Díaz de Solís. Bermúdez no cuestiona que el encuentro de las tropas haya sido con charrúas, suobjetivoes aclararelepisodiodelamuerte.Suprincipalargumentose vincula al origen de la versión la cual surge años después de la muerte del explorador.Bermúdezcuestionalos detalles deesa versión pues le parecepoco probableque,quieneshabían logradoescapar,corrieranel peligrodepermanecer espiand o para saber el futuro de sus compañeros. Por todo eso señala:

“Fuera posible que unos cuantos años de intervalo hubiesen cambiado totalmente sus instintos? Aceptaremos un hecho aislado y dudoso de barbarie, no creído por [Félix de] Azara y negado por [Alcides] d'Orvigni cuando en contraste resaltan muchos y auténticos de una humanidad comprobada"64.

\footnotetext{
62 Nos referimos al poema épico "La Argentina y conquista del Río de la Plata", publicado por el sacerdote Martín del Barco Centenera a principios del siglo XVII.

${ }^{63}$ BERMÚDEZ, Pedro P. Ob. Cit., p. 115

${ }^{64}$ Ibídem, p. 114.
} 
¿Pero cuál fue la recepción que tuvo El Charrúa? En 1853, su publicación parece no haber generado ninguna polémica. Los apoyos y críticas tomaron estado público en 1858 cuandoel drama histórico fue presentadoenelTeatro Solís de Montevideo por una compañía española. En el diario "La Nación”, "UnosOrientales"felicitóla obra deBermúdez.Enrespuesta,FranciscoXavier de Acha polemizó con el autor de la nota anónima, no solo criticando su pretendida calidad literaria, sino sobre todo tachando la vindicación de Bermúdez hacia los charrúas asociada a una crítica al legado español. Como señala Fabio Wasserman, la inclusión de los charrúas en la memoria colectiva traía aparejadosalgunosinconvenientes:"Esque[loscharrúas]nosólohabíansobrevividoalosesfuerzoshechosporlosespañolesparasometerlos,sinoquetambiénhabíancombatidocon-ycontra-losejércitosrepublicanoshastaquefueronexterminadosen1831"65.

\section{Los "indios charrúas" de bronce}

Losintentos más exitosos dela incorporación positiva de los indios charrúas, asociados a conceptos como el de "valentía"e "independencia", fueron en la década de 1880 cuando se concretaba en el Uruguay el proceso de consolidación de la identidad nacional. En 1879 el historiador colorado y católicoFranciscoBauzápublicólaHistoriadeladominaciónespañolaenelUruguay. LaobradeBauzá,consideradacomo"fundadoradelrelatodelosorígenes" ${ }^{\prime \prime 6}$,ensu esfuerzo por demostrar el carácter prefigurado de la nación, incorporó la noción de"indios uruguayos", entre los que incluyó a los charrúas. En la primera parte del tomo uno, Bauzá realiza una descripción en la que expresa la existencia, a la llegada del español, de los charrúas como una sociedad organizada cuyo predominio se extendió en el actual territorio del Estado uruguayo.

Losindioscharrúasson presentadoscomoun pueblo"salvaje"cuyascondiciones morales son una mezcla de "bondad natural" $y$ "valentía heroica":

\footnotetext{
${ }^{65}$ WASSERMAN, Fabio. Ob. Cit., p. 128.

${ }^{66}$ DEVOTO,Fernando.Laconstrucción del relatodelosorígenesen Argentina, BrasilyUruguay:lashistorias nacionales de Varnhagen, Mitre y Bauzá. En MYERS, Jorge. Historia de los intelectuales en América Latina. Buenos Aires: Katz, 2008. p. 278.
} 
"La lucha por la existencia emprendida todos los días contra la naturaleza y sus semejantes,y frecuentementecontraambosala vez, les había dadolaconciencia de su valor, sin ninguno de los agregados con que la vanidad suele afear ese don tan precioso en el hombre. No eran crueles con los vencidos, ni brutales con la mujer, ni autoritarios con los niños $[. . .]^{167}$

A lo largo de la obra se advierte el peso de las crónicas y relatos de viajeros europeos, a partir de las cuales el autor ilustra las características de la población nativa a la llegada de los españoles. La visión de los charrúas es inmutable, para Bauzá sólo se vincularon con la población hispanocriolla a travésdelaviolenciaydesdesiempre"constituidosencuerpodenación"68.Bauzá hace uruguayos a los charrúas, "su nación", como señala Carlos Zubillaga, eraunanticipodeésta:"laindependenciadelUruguay[estaba]delargotiempoatrás preparadaporlaposicióntopográficadelterritorioyporlastendenciasdesushabitantes" ${ }^{\prime \prime 9}$.

Al mismo tiempo, el pintor Juan Manuel Blanes realizó algunas obras centradasenlatemáticaindígenalascualesreflejanestecambiodevaloración quevenimosadvirtiendo.BlanesfuemiembrofundadordelaSociedadCienciasyArtesdesde1876.Aunquenotomóposicionespúblicasenlasdiscusiones dela intelectualidad, estuvo interesado en diversos temas, comolo demuestra esta correspondencia que mantuvo con su hermano Mauricio en 1881:

"[...] en el Ateneo, todo es lengua suelta... Esos atenienses son enemigos de la historia nacional, y no saben que Zapicán y Abayubá no conocieron el venéreo, ni la sífilis, ni fueron traidores, y aunque no tuvieron noticia de los Papas ni los romanos, tenían sus leyes [... $]^{\prime 10}$

${ }^{67}$ BAUZÁ, Francisco. Historia dela Dominación española en el Uruguay.Tomol, Montevideo:Ministerio de Instrucción Pública y Previsión Social, 1965. p. 207

${ }^{68}$ BAUZÁ, Francisco. La Independencia del Uruguay. Enciclopedia Uruguaya, "Independencia, anexión, integración" Juan C. Gómez- Francisco Bauzá. № 16 Montevideo, octubre de 1968, p. 143.

69 ZUBILLAGA, Carlos. Historia e historiadores en el Uruguay del siglo XX. Montevideo: Facultad de Humanidades y Ciencias de la Educación, 2002. p. 48.

${ }^{70}$ Citado en PELUFFO LINARI, Gabriel. Historia de la pintura uruguaya. Tomo 1. El imaginario nacional - regional (1830 - 1930). Montevideo: Ediciones de la Banda Oriental, 1999. p. 20. 
Esa preocupación por la temática indígena se refleja en su obra La cautiva, de $1880^{71}$. Allí aparece representado uno de los temas principales de la pintura y la literatura del siglo XIX en el Río de la Plata: el rapto de las mujeres por las parcialidades indígenas. En un primer plano, una cautiva mira al cielo en un sentimiento de abatimiento mientras, a su lado, un indio la observa. La imagen demuestra el lugar de la cautiva entre los indios, el contraste entre los dos mundos, destacados por la iluminación que recibe el cuerpo de la mujer. En un segundo plano, Blanes representa la horda salvaje, con la llegada de los indios a la toldería a su regreso del malón.

Además en esos años trabajó en El ángel de los charrúas ${ }^{72}$ basado en un poema titulado de igual forma cuyo autor es el poeta católico Juan Zorrilla de San Martín. En la imagen una mujer indígena, sin alas, y despojada de toda alusión violenta, representa al "ángel" de los charrúas. Se trata de una representación apacibleque se distancia delas actitudes deguerra más referidas por la iconografía.

El poema de Zorrilla resalta los valores de los charrúas, "raza vencida" que se "extinguióo", "sin dar un paso hacia atrás":

“'Cadenas! ¡Pobres charrúas!

¡Ay de la raza vencida!

¡Cayó una raza inocente!

Sin dar un paso hacia atrás

Dobló la bronceada frente.

¡Cayó una raza inocente!

Para no alzarse jamás." ${ }^{173}$

71 Juan Manuel Blanes, “La cautiva”, óleo sobre tela, 102 x 77,5 cm, 1880, Montevideo, Museo Municipal J. M. Blanes. Agradezco la referencia al Lic. Ernesto Beretta García.

72 Juan Manuel Blanes, “El ángel de los charrúas", óleo sobre tela, 100 X 80 cm, 1880-1883, Montevideo, Palacio Estévez. Agradezco la referencia a Ernesto Beretta García.

73 MUSEO DE ARTE PRECOLOMBINO E INDÍGENA (MAPI), Imaginarios prehispánicos en el Arte Uruguayo: 1870-1970. Montevideo, MAPI, 2006. p. 78 


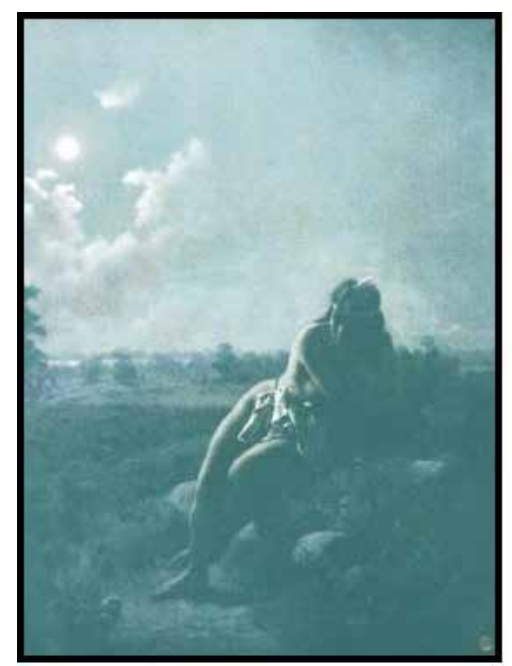

Imagen VII

Juan Manuel Blanes, "El ángel de los charrúas", óleo sobre tela, $100 \times 80 \mathrm{~cm}$, 1880-1883, Montevideo, Palacio Estévez.

En el momento en que Blanes produjo su obra artística ya no existían comunidadesindígenasviviendoentolderías, ¿entonceselángeleselalmade los charrúas? ¿Lo que permanece es un espíritu vencido pero sobreviviente inocentemente?

ComoseñalaelhistoriadoruruguayoCarlosZubillaga“Laconcepcióndel tempranodiseñonacional,buscólosrasgosdeidentidadenelpasadoindígenayenla continuidaddeunavocaciónsoberana,queatravesóelperíodocolonialylasluchaspor la independencia". En este sentido, tanto la obra de Francisco Bauzá como la producción literaria de Juan Zorrilla de San Martín fueron gestoras de esta opinión y, aunque no existía una "comunidad historiográfica", sus relatos configuraron la tesis nacionalista ${ }^{74}$.

En 1888 Juan Zorrilla de San Martín publicó Tabaré, poema que generó un fuerte impacto a nivel de la opinión pública. En la obra, el autor narra el

${ }^{74}$ ZUBILLAGA, Carlos. Ob. Cit., p. 48- 49. 
idilio entre el indio Tabaré, personaje principal de la historia e integrante de una tribu charrúa, y Blanca, una mujer española. El poema está dividido en diez cantos y se ambienta en el contexto del ocaso de la etnia charrúa.

EnTabaréaparecenviejostemassobrelosvínculosentreamerindiosehispanocriollos. Tabaré (un mestizo) y Blanca (una española) encarnan los conflictosytensionesentrelasociedadcriollayelmundoindígena.Eneldesenlace del poema muere Tabaré, como metáfora de la desaparición de su "raza"75.

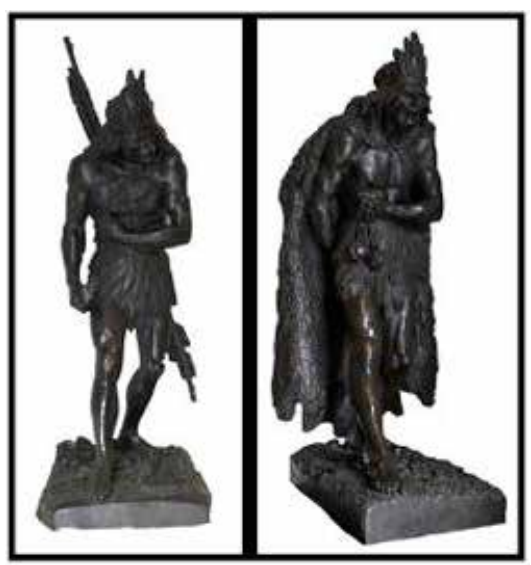

Imagen VIII

Juan Luis Blanes, Abayubá, bronce, $38 \times 65 \times 138 \mathrm{~cm}, 1887$.

Nicanor Blanes, Zapican, bronce, 38 × 128 × 63,5 cm, 1880 - MHN CAI 2832.

El poder de lo simbólico se expresó de forma efectiva a través dela escultura. Nicanor Blanes realizó en 1880 el yeso del cacique Zapicán, su hermano Juan Luis, culminó en 1887 el del cacique Abayubá. Los yesos fueron años más tarde utilizados para las versiones en bronce, las cuales se encuentran en el hall de entrada de la Casa de Rivera, perteneciente al Museo Histórico Nacional en Montevideo. Se trata de la representación de dos guerreros,

75 ZORRILLA DE SAN MARTíN, Juan. Tabaré. Buenos Aires: Editorial Kapelusz, 1965. p. 205. 
sinónimo dela resistencia hasta el final, cuando ambosfueron exterminados por las tropas de Juan de Garay en el combate de San Salvador en 1574.

El cacique Zapicán está en actitud de acecho, su brazo izquierdo está sobre su pecho mientras sostieneen sumano unjuego de boleadoras depiedra. Lleva por vestimenta la piel de un animal que lo cubre hasta sus tobillos. Abayubá está en una actitud similar a la de Zapicán, en su mano derecha empuña una maza y en la izquierda una correa que sostiene un carcaj con el arco y las flechas. Está semidesnudo, alhajado con un tocado de plumas y cubierto con una pequeña falda.

Un último ejemplo permite advertir el cambio en la valoración del indígena asociado a la construcción de la identidad nacional. Durante la década de 1880, Juan Manuel Blanes trabajó en su obra titulada"Alegoría de América Republicana". La "América Republicana" es representada por un indio a caballo, montado en pelo, que sostiene en sus mano derecha unas cadenas rotas como imagen de la independencia y el abandono del "yugo" español. La actitud es de combate, aspecto fortalecido por las flechas que empuña en su mano izquierda. La imagen del indio se concreta junto a la de la independencia y la república. En el “Resurgimiento de la Patria" de 1898, Blanes pinta una escena en la bahía de Montevideo donde en primer plano una república femenina envuelta enel pabellón nacional estáacompañadadeun indioque la observa desde el suelo. Ella está sentada sobre una piedra donde se ha colocado una piel de jaguar. El indio está ataviado con la misma piel, observando. En un segundo plano aparece la fortaleza de Montevideo y un barco entrando a la bahía.

Al igual que la mayoría de las imágenes que hemos señalado, la obra de Blanes resaltalosaspectos"guerreros"delastribuscharrúas, peroadiferencia de Onslow y Debret, ese carácter tiene ahora una lectura positiva, pues es sinónimo de su temple“heroico"e"indomable" frente al yugo de la conquista.

\section{Palabras finales}

El proceso no fue unívoco. La valoración positiva o negativa de los "indioscharrúas"fuepermeandolas representaciones textualesy plásticasenel contexto de la afirmación del Estado Oriental y la formulación de una identidad nacional. Aunque el proceso no fue lineal, la idea del charrúa asociado 
al concepto de "salvaje", acepción común a principios del siglo XIX, fue releídaporalgunosasusfinalescomosinónimodelibertadeindependencia. Así lo señalaba el diplomático francés conde de Saint Foix, cuando escribía: "Eranenfinunanaciónguerreraquepreferíalamuertealapérdidadelalibertad" ${ }^{\text {"76 }}$.Esa caracterización de los"indios charrúas" llegó a convertirse en un ejemplo de "moral cívica". En 1903 Enrique Antuña, en la primera lección de su texto de moral cívica, incluyó a los "indios charrúas" al referirse a la "abnegación por la patria", es decir a la capacidad del sacrificio personal por el bienestar de la nación. Los indios charrúas, presentados como los "dueños primitivos" del territorio queocupa elUruguay, se habían“abnegado porla patria”ya que "prefirieronserexterminadosasometersealaleydesusconquistadores,fueranéstoslos europeososusdescendienteslosorientales ${ }^{\prime \prime 7}$. Encontrasteconestaideapersistían los significados negativos sobre el pasado indígena. Un texto escolar de amplísima difusión en la primera mitad del siglo XX, cuyo autor era Eduardo Gilberto Perret Vuagnoux, más conocido como HD, incorporaba a su vez una lectura confesional sobre el pasado que consideraba la ausencia de los "indios charrúas" como una "bendición":

"[Los charrúas] Como todos los demás indios de América, eran paganos, es decir que no conocían al verdadero Dios. Ignoraban nuestra santa religión, y vivían casi como animales. Eran pues, muy desgraciados. Hay todavía en la tierramuchospueblosquesonsalvajescomoloeranlosprimeroshabitantesde nuestro país. Niños, debéis agradecer mucho a Dios y amarle con todo vuestro corazón, por haberos hecho nacer civilizados y cristianos." ${ }^{178}$

Alcomponenteidentitariosesumabalainsistenciaenlaexcepcionalidad del Uruguay en relación a otros países de América. En el contexto del centenario de la independencia, como señalaron Cecilia Ponte y Susana Antola:

${ }^{76}$ SAINT FOIX. La Republique Orientale de L'Uruguay. Historie, Geographie, Moeurs et coutumes commerce et navigation, agricultura par Le Comte de Saint Foix (ministre Plenipotetiaire). Paris: Libraire Lépold Cerf, 1892.

77 ANTUÑA,Enrique.Temas demoralcívicailustradosconejemplostomadosdelaHistoriaNacional.Montevideo: Tipografía Nacional de la Escuela de Artes y Oficios, 1903. pp. 10-11.

${ }^{78} \mathrm{HD}$ [Hermano Damasceno]. Curso de Historia Patria, libro primero (curso elemental). Montevideo: A. Barreiro y Ramos Editor, Librería Nacional, 1903. p. 3. 
“[...] para convocar la emoción se expresó con contundencia en la creación de una iconografía de la nación, a través de imágenes pictóricas que congelaron la historia patria a la manera de un drama en varios actos, cada uno de ellos condensandoen una imagen verosímily pedagógica, degranfuerza expresiva y amplia difusión, que se impuso en el imaginario colectivo" ${ }^{\prime \prime 9}$.

En 1925 al editarse el Libro del Centenario, se dejaba en claro, en su introducción, la "singularidad" del Uruguay, habitado "por la raza blanca, en su totalidad de origen europeo". En las primeras páginas los autores celebrabanquehacía“[...]casiunacenturiaquedólatierrauruguayaenposesiónabsoluta delarazaeuropeaysusdescendientes,','hombreslaboriosos"quehabitabantodo el territorio. Esa imagen simbólica de un país homogéneo desde el punto de vista étnico rechazaba también a los "etíopes":

"Puebla el Uruguay la raza blanca, en su totalidad de origen europeo. La raza indígena que habitaba esta región de América cuando el descubrimiento y la conquista, ya no existe, siendo el único país del continente que no cuenta en toda la extensión de su territorio tribus de indios, ni en estado salvaje, ni en estado de domesticidad. Mezclada su sangre con la de la raza conquistadora, tiende a perder los leves vestigios ancestrales que aún conserva, por el cruzamiento y trasfusión continuada de la raza europea. La pequeña proporción de raza etiópica introducida al país por los conquistadores españoles, procedente del continente africano, a fin de establecer la esclavitud en estas tierras, disminuye visiblemente hasta el punto de constituir un porcentaje insignificante en la totalidad de la población. Por otra parte, sus características originales han sufrido, por el clima, circunstancias de medio ambiente, y por mezcla de la sangre europea, modificaciones fundamentales" 180

En el Novecientos, aunque la historiografía incorporó a los "indios charrúas"en la identidad nacional, al mismo tiempo se apreció de forma positiva la excepcionalidad del Uruguay, como único país de América sin presencia de indígenas, una república "civilizada" y similar a cualquiera de Europa.

79 PONTE, Ceciliay ÁNTOLA, Susana."La nación en bronce, mármol y hormigón armado”en CAETANO, Gerardo (dir.) Los uruguayos del Centenario. Nación, ciudadanía, religión yeducación (1910-1930), Montevideo: Taurus, 2000, p. 220.

80 LÓPEZ CAMPAÑA, Perfecto. El Libro del Centenario. Montevideo: Agencia de Publicidad Capurro, 1925, p. 43. 
Como ha señalado el historiador Gerardo Caetano"el modelo ciudadano'hiperintegrador"delUruguaymodernomostródoscarascontrastantes, porun lado el disciplinamiento, el deseo de la homogeneidad racial, y por otro lado elhumanismoycosmopolitismorepresentados porelbatllismo,"integración generosaperoconelcostodelasanciónaladiferenciaparecíanserasílosdospoloscontradictorios de esa síntesis compleja y polémica"81.

\section{Bibliografía}

ACOSTA Y LARA, Eduardo F. La guerra de los charrúas. Montevideo: Talleres de Loreto Editores, 1998.

ANTUÑA,Enrique.TemasdemoralcívicailustradosconejemplostomadosdelaHistoria Nacional. Montevideo:Tipografía Nacional de la Escuela de Artes y Oficios, 1903.

ARAÚJO, Orestes. Historia de la escuela uruguaya. Montevideo: El Siglo llustrado, 1911.

BANDEIRA, Julio; CORREA DO LAGO, Pedro. Debret e o Brasil: obra completa: 1816 - 1831. Río de Janeiro: Capivara, s.f.

BAUZÁ, Francisco. Historia de la Dominación española en el Uruguay, Tomol. Montevideo: Ministerio de Instrucción Pública y Previsión Social, 1965.

BAUZÁ,Francisco.LalndependenciadelUruguay.EnciclopediaUruguaya,"Independencia, anexión, integración" Juan C. Gómez- Francisco Bauzá. № 16 Montevideo, octubre de 1968.

BECHIS,Martha.Rostrosranquelinos..._rostrosranquelinos?:eldibujohistórico en problemas. Boletín Tefros, Río Cuarto, volumen 1, n 2, invierno 2004, disponible en http://tefros.equiponaya.com.ar/revista/.

BERMÚDEZ, Pedro P. “El Charrúa”. Drama histórico en verso. Montevideo: Imprenta de El Orden, 1853.

CABELLA, Wanda; NATHAN, Mathías. Iguales y diferentes. En Colección Nuestro Tiempo, libro de los bicentenarios, no 20, p. $17-18$, disponible en http://www.bibliotecadelbicentenario.gub.uy/innovaportal/ file/62986/1/nuestro-tiempo-20.pdf.

${ }^{81}$ CAETANO, Gerardo. La República Batllista. Montevideo: Ediciones de la Banda Oriental, 2011, p. 35. 
CABRERA PÉREZ, Leonel; BARRETO, Isabel. Indios, frontera y hacendados en el sur de la Banda Oriental. En: BEHARES, Luis; CURES, Oribe. Sociedad yculturaenelMontevideocolonial.Montevideo:FacultaddeHumanidadesy Ciencias de la Educación, 1997.

CABRERA PÉREZ, Leonel; BARRETO, Isabel. El ocaso del mundo indígena y lasformasdeintegraciónalasociedadurbanamontevideana.RevistaTEFROS, Río Cuarto, Vol. 4 №2, Primavera de 2006.

CAETANO, Gerardo. La República Batllista. Montevideo: Ediciones de la Banda Oriental, 2011.

CAETANO,Gerardo (coordinador). Historia conceptual.Vocesyconceptos de la política oriental (1750 - 1870). Montevideo: Ediciones de la Banda Oriental, 2013.

CARÁMBULADEBARREIRO, Margarita. A la heroica muerte del bravo coronel don Bernabé Rivera. Revista Histórica, Montevideo, Tomo XVI, pp. 491 503, 1949.

CELESTINO DE ALMEIDA, Regina. Índios mestiços e selvagens civilizados de Debret:reflexõessobrerelaçõesinterétnicasemestiçagens.BeloHorizonte: Varia Historia, vol. 25, n 41, pp. 85 - 106, 2009.

DÁVILA,Adriana;AZPIROZ,Andrés. Indios,cautivosyrenegadosenlafrontera. Los blandengues y la fundación de Belén 1800- 1801. Montevideo: Ediciones Cruz del Sur, 2015.

DEVOTO,Fernando.LaconstruccióndelrelatodelosorígenesenArgentina,BrasilyUruguay: las historias nacionales de Varnhagen, Mitre y Bauzá. En: MYERS, Jorge.HistoriadelosintelectualesenAméricaLatina.BuenosAires:Katz,2008.

DOMÍNGUEZ, RAMÓN JOAQUÍN. Diccionario Nacional o Gran Diccionario Clásico de la Lengua Española (1846-47). Madrid-París: Establecimiento de Mellado, 1853, 5 a edición. 2 vols, disponible en: rae.es/ntlle

FERNÁNDEZ SEBASTIÁN, Javier; CAPELLÁN DE MIGUEL, Gonzalo. Conceptospolíticos,tiempoehistoria.Santander:EditorialdelaUniversidad de Cantabria, 2013.

FIGUEIRA,JoséJoaquín.“ElcaciquecharrúaVaimacaPerúfue soldadode Artigas" en "Artigas", Suplemento diario Acción, Montevideo, 18 de junio de 1964, p. 30.

FIGUEIRA,JoséJoaquín.EduardoAcevedoDíazylosaborígenesdelUruguay.3tomos. Montevideo: Estado Mayor del Ejército, Departamento de Estudios Históricos, División Historia, 1977. 
FORNARO, Marita; SALOM, Marta; CARREÑO, Graciela y otros. PresenciaeinfluenciaespañolaenelTeatroSolísdeMontevideo(1856-1930):zarzuelas, sainetes, cupleteras y tangos. Cuadernos de Música Iberoamericana, s/d, vol. 13, 2007.

FREGA,Ana(coord.).Uruguay:Revolución,independenciayconstruccióndelEstado. Tomo 1- 1801- 1880. Montevideo: Planeta, Fundación Mapfre, 2016.

[GASPAR Y ROIG]. Biblioteca Ilustrada de Gaspar y Roig. Diccionario enciclopédicodelalenguaespañola,contodaslasvozes,frases,refranesylocuciones usadas en España y las Américas Españolas, Tomo I. Madrid: Imprenta y Librería de Gaspar y Roig, editores, 1853. Disponible en: rae.es/ntlle

HD [Hermano Damasceno].Curso de Historia Patria, libro primero (curso elemental). Montevideo: A. Barreiroy Ramos Editor, Librería Nacional, 1903.

HOLANDA, Sergio Buarque de.Oprocesso deemancipação. Em___org) Historia geral da civilização brasileira. Tomo ll: O Brasil Monárquico. Vol 1:O processo de emancipação. San Pablo: DIFEL, 1985.

HOUOT,Annie.Uncaciquecharrúa en Paris.Montevideo:ImprentayEditorial Costa Atlántica, 2002.

HOUOT,Annie.GuaraníesycharrúasenlaliteraturauruguayadelsigloXIX:realidad y ficción. Montevideo: Editorial Linardi y Risso, 2007.

ISLAS, Ariadna. Marianne no está sola. A propósito de la iconografía y el concepto de la república en la estatuaria en el Uruguay 1830-1930, ponencia presentada en el Coloquio Internacional “El lenguaje político más allá de la política. Hacia una historia de los conceptos sociales, culturales y jurídicos en los mundos ibéricos, siglo XVIII- XX", Casa de Velázquez, Madrid, 5-6 de setiembre de 2016.

KOSELLECK, Reinhart. Futuro pasado. Para una semántica de los tiempos históricos. Barcelona: Paidós, 1993.

LÓPEZ CAMPAÑA, Perfecto. El Libro del Centenario. Montevideo: Agencia de Publicidad Capurro, 1925.

MUSEO DE ARTE PRECOLOMBINO E INDÍGENA (MAPI). Imaginarios prehispánicosen el ArteUruguayo:1870-1970.Montevideo:MAPI, 2006.

ODDONE, Juan Antonio. La historiografía uruguaya en el siglo XIX. Apuntes para su estudio. Revista Histórica de la Universidad, Montevideo, Segunda época, n 1, 1959. 
ONCINA,Faustino.Koselleckyelgiroicónicodelahistoriaconceptual.RevistaAnthropos: Huellas del conocimiento, no 223, pp. 71- 81, 2009.

PADRÓNFAVRE, Oscar.Sangreindígena en elUruguay.Montevideo:Editorial Barreiro, 1987.

PELUFFO LINARI, Gabriel. Historia de la pintura uruguaya. Tomo 1. El imaginario nacional - regional (1830 - 1930). Montevideo: Ediciones de la Banda Oriental, 1999.

PIHUGARTE, Renzo. Historias de aquella"gente gandul". Españoles y criollos vs indios en la Banda Oriental. Montevideo: Editorial Sudamericana Uruguaya y Editorial Fin de Siglo, 2005.

PONTE, Cecilia y ÁNTOLA, Susana. “La nación en bronce, mármol y hormigón armado"enCAETANO,Gerardo(dir.).LosuruguayosdelCentenario.Nación, ciudadanía, religiónyeducación(1910-1930). Montevideo:Taurus, 2000.

PORZECANSKI, Teresa. Las raíces indígenas: mito y realidades. En: La Gaceta Revista de la Asociación de Profesores de Historia del Uruguay, Montevideo, n²2, abril 2002.

PRICHARD, James Cowles. Histoire naturelle del'homme.Tomoll.Paris: Chez J. Bailliere, 1843.

RAMA, Germán.La democracia en Uruguay.Una perspectiva de interpretación. Montevideo: Editorial Arca, 1989.

RIVET, Paul. Los últimos charrúas. Montevideo: Ediciones de la Plaza, 2003.

SAINTFOIX.LaRepubliqueOrientaledeL'Uruguay:Historie,Geographie,Moeurs et coutumes commerce et navigation, agricultura par Le Comte de Saint Foix (ministre Plenipotetiaire). Paris: Libraire Lépold Cerf, 1892.

TERREROS Y PANDO, ESTEBAN DE. Diccionario castellano con las voces de cienciasyartesysuscorrespondientesenlastreslenguasfrancesa,latinaeitaliana[...]. Tomo primero, Madrid, Viuda de lbarra, 1786. Disponible en: rae.es/ntlle.

TREVISAN,AndersonRicardo.Velhasimagens, novosproblemas.Aredescoberta de Debret no Brasil modernista (1930-1945). Tesis de Doctorado en Sociologia, Programa de Posgraduación en Sociología. San Pablo: Universidade de São Pablo, 2011.

WASSERMAN, Fabio. Entre Clio y la Polis. Conocimiento histórico y representaciones del pasado en el Río de la Plata (1830-1860). Buenos Aires: Editorial Teseo, 2008. 
WEBER,DavidJ.Bárbaros.Losespañolesysussalvajesdelaeradelailustración. Barcelona: Editorial Crítica, 2007.

ZORRILLA DE SAN MARTíN, Juan. Tabaré. Buenos Aires: Editorial Kapelusz, 1965.

ZUBILLAGA, Carlos. Historia e historiadores en el Uruguay del siglo XX. Montevideo: Facultad de Humanidades y Ciencias de la Educación, 2002.

Recebido: 02/08/2016 - Aprovado: 15/02/2017 